\title{
The STAR Framework: Towards a more Communicative EFL Class
}

\author{
El formato STAR: hacia una clase de ESL más comunicativa
}

\author{
Cinthya Olivares Garita \\ Universidad Nacional de Costa Rica \\ Lena BarRantes Elizondo \\ University of Calgary, Canadá \\ Verónica BREnes SÁNCHEZ \\ Universidad Nacional de Costa Rica
}

\begin{abstract}
English instruction needs to be transformed to provide learners with a suitable environment that allows them to interact in real life situations. For this reason, Task-based Instruction (TBI) has been included into a communicative framework to offer opportunities for learners to use the language without penalizing them for inevitable failures in accuracy, motivating them to engage in the learning process (Willis \& Willis, 2007). Inspired by the TBI methodology, a framework called STAR was created to intensify the use of communication in each stage of the lesson (starter, tackle, automatization and recycling stages). Bearing this in mind, the purpose of this qualitative study is to demonstrate the extent to which STAR fosters a more communicative environment for English teaching. This research was conducted in a language program in a public university in Costa Rica, where twenty-five English teachers were consulted about the effectiveness of the framework; added to this, classroom observations and researchers' logs provided a deeper understanding about the role of STAR. The results evinced the effectiveness of the use of communicative activities within the framework proposed to foster spontaneous speech, heighten engagement, increase risk taking skills, boost learners' autonomy and build up collaboration in the EFL classroom.
\end{abstract}

Keywords: TBI, communicative framework, methodology, engagement, autonomy 


\section{Resumen}

La enseñanza del inglés necesita ser transformada para proveer a los estudiantes con un ambiente apropiado que les permita interactuar en situaciones de la vida real. Debido a esto, la instrucción por tareas (Task-based Instruction) ha sido incluida en la metodología comunicativa para ofrecer oportunidades a los estudiantes de utilizar el lenguaje sin sentir temor por los errores inevitables que cometan, motivándolos a involucrarse en el proceso (Willis y Willis, 2007). Inspirado en la instrucción por tareas, el formato llamado STAR fue creado para intensificar la comunicación en cada etapa de la lección. Con esto en mente, el propósito del siguiente estudio cualitativo es demostrar el alcance del formato de clase STAR para desarrollar un ambiente más comunicativo en la enseñanza del inglés. Esta investigación fue llevada a cabo en un programa de inglés de una universidad pública en Costa Rica, donde veinticinco profesores de inglés fueron consultados sobre la efectividad del formato por medio de un cuestionario. Además, las investigadoras realizaron observaciones de clase, obteniendo bitácoras para una mejor comprensión del rol del formato. Los resultados de este estudio evidencian la efectividad de actividades comunicativas bajo el formato propuesto para fomentar el uso espontáneo del lenguaje, la participación, las habilidades para tomar riesgos, la autonomía y la colaboración en el aula.

Palabras clave: instrucción por tareas, formato comunicativo, metodología, involucramiento, autonomía

\section{Introduction}

$\mathrm{E}$ ffective communication is the ultimate goal in language learning. Under the premise that English instruction has evolved to provide students with the skills to accomplish such a goal, different methodologies have been developed to boost communicative competence. Richards (2006) described effective communication as the "mastery of functions needed for communication across a wide range of situations" (p. 11). In this pursuit, Task-based Instruction (TBI) has been embraced by the Communicative Framework to "take real life tasks as the source and model for pedagogical actions" (Sánchez, 2004, p. 52) where students will use the language in real life-like situations.
This paper reports the results of a study conducted to analyze the extent to which a particular framework designed promotes more communicative classes. It presents the findings of a case study conducted with 25 teachers and one program developer at a language school in a state university in Southern Costa Rica. The research questions formulated as a foundation for this research are:

- To what extent does the STAR framework promote communicative opportunities in the EFL class?

- What strategies and activities can boost students' linguistic skills with a communicative focus within the STAR framework? 


\section{Literature Review}

Promoting more communicative classes has always been a challenge for EFL instructors. Numerous efforts to guarantee the development of oral communication can be traced back in the history of language teaching during the early 1970s up to the present.

To what extent does the STAR framework promote communicative opportunities in the EFL class?

The STAR framework was designed under the premise that English language teaching should promote the development of the oral skill. The following concepts are significant elements in the design of the STAR framework.

Task-based instruction. Task-based Instruction rises as an approach to syllabus design based on the search for genuine communication. The basis for organizing a more communicative syllabus is centered on tasks. Finding one uniform definition of task seems difficult to provide. Nevertheless, experts on the field have made several attempts to give one. Though Richards (2006) believed that the definition of a task is controversial and confusing, he stated some features to distinguish tasks from exercises or other types of activities. He emphasized that a task is something that learners carry out using their existing language resources, it has an outcome which is not simply linked to learning language, it involves a focus on meaning and, finally, in the case of tasks involving two or more learners, it calls upon the learners' use of communication strategies and interactional skills. For every task, there must be a defined purpose; examples of tasks would be filling out a form, buying a pair of shoes, making an airline reservation, borrowing a library book, taking a driving test, typing a letter, making a hotel reservation, writing a check, finding a street destination and helping someone across the road (Brandl, 2008).

Depending on the nature of the task, Nunan (2004) has distinguished tasks as real-world tasks or pedagogical tasks. The former relates to those activities that enable the learner to act and function in the world outside the classroom. Therefore, these types of tasks aim to facilitate understanding of the communicative skills used in more natural-occurring environments and constitute the ultimate aim of a lesson or unit. On the other hand, the latter work as a preparation to provide learners in the classroom with the real language needed to interact outside. Long (1985) based the development of communicative competence on the use of real-life or target tasks. He defined target tasks as "a piece of work undertaken for oneself or for others, freely or for some reward. [...] In other words, task means the multiple things people do in everyday life, at work, at play and in between" (p. 89). These tasks have proved to foster communication through the exposure of learners to simulations of life-like scenarios.

Later on, Prabhu (1987) popularized TBI and stated that among other features, a task must face the learner with some sort of "gap." Thus, he identified three main types: information gap, reasoning gap and opinion gap. Any of these could foster the participation of the interlocutors in the conversation at an equal amount when they are encouraged to fulfill a defined goal. The first meaning-based task is 
defined as one that facilitates negotiation of meaning through the transfer of information to complete a given piece of text (oral or written). The reasoning task involves comprehension and conveyance of the appropriate information derived from a given text through deduction, inference and practical reasoning. The opinion gap task stimulates the expression of preferences, feelings and attitudes according to a defined situation.

To accommodate the TBI methodology into a lesson design, the teacher may follow a given framework: pretask, during-task and post-task (Ellis, 2010). The pre-task stage is aimed at preparing students with the structures and vocabulary appropriate for them to interact and produce language during the task. Newton (2001) pointed out some ways to cover new linguistic structures and vocabulary during this phase such as predicting, cooperative dictionary search, and words and definitions. The time spent for the pre-task phase is pivotal to the mastering of the lexicon necessary to interact during the rest of the lesson. Learners are prepared with enough input, which must be rich, comprehensible and elaborated, for their successful performance during the following stage.

The during-task phase is expected to occur when students are so involved in using the new linguistic forms that they are able to retain the structures and lexicon with ease. For this involvement to happen, three factors are required: need for comprehension (a defined reason to learn the forms), search (making attempts at discovering the word needed), and evaluation (assessing how effective words are in a given text). Strategies like glossaries, interactive glossaries and negotiation can be used in this stage (Newton, 2001). The post-task is an enhancement phase in which vocabulary and structures can be revised and encountered again in more different contexts through various other techniques. Some post-task techniques can include "revision tests, quizzes, group activities involving review and analysis of new vocabulary, and systems for learners to independently record and revise new vocabulary" (Newton, 2001, p. 36). The goal is to facilitate language retention and internalization through more complementary activities.

It is worth mentioning that TBI comprises seven principles to language teaching. First, scaffolding, which is the support needed for learners to get ready and produce language by themselves. Second, task dependency illustrates the chain of subsequent tasks, one building upon the other where learners must move from more receptive to productive tasks. Third, recycling consists of reintroducing a linguistic item various times after being presented and using it in different linguistic contexts. Fourth, active learning relates to the principle that students must be active for learning to take place. Fifth, the integration of linguistic forms with communicative function and semantic meaning enables the learners to interact with their interlocutors more effectively. Sixth, reproduction to creation targets the ability of the learners to recombine linguistic items already learned in creative ways. Seventh, reflection deals with the capacity of the learners to reflect upon their linguistic progress and act accordingly (Nunan, 2004).

Along with key guiding TBI principles, the analysis of the effectiveness of 
the STAR framework in this study is informed by relating concepts: authenticity, learner autonomy, motivation, engagement, participation and assessment.

Authenticity. The implementation of TBI in language classrooms requires the use of richly specified input, which in time has come to include some imperative conditions. One of these conditions is authenticity, which relates to any stretch of language that proves to be a real and genuine representation of the language native speakers of English use, and how they use it in daily life to interact (Brown, 2015). Based on Gillmore's (2007) assumptions, the concept of authenticity can be found either in the text itself, in the participants, in the social or cultural situation and purposes of the communicative act, or a combination of these (p.89). These relevant data guide the teacher to make informed decisions about the resources and materials brought to the classroom.

In terms of this study, the use of authentic activities and materials takes prominence in the realization of the STAR framework. In this regard, the most known and used definition for authentic materials is that one by Carter and Nunan (2001), who defined these types of language resources as "ordinary texts not produced specifically for language teaching purposes" (p. 68). These resources differ from teacher-created materials in the sense that authentic resources are taken from their real and natural context to be exploited academically as they represent real-life situations, events or language simulated in a classroom. They provide learners with exposure to real language, and its use in its own community (Kilickaya, 2004). In an EFL context, the more students benefit from language practiced by the use of materials resembling real life, the more opportunities they get to maximize their level of competence and function in the outside world. Some revealing aspects about authentic resources pointed out by Richards (2001) include preparing learners for real life, meeting learners' needs, affecting learner's motivation positively, encouraging teachers to adopt effective teaching methods and presenting authentic information about culture.

Learner autonomy. A significant concept to language teaching is learner autonomy. Most of the students' limitations to learn the language lie in the lack of self-learning strategies. Holec's (1981) definition of autonomy is, possibly, one of the most used to conceptualize learner autonomy. He stated that autonomy is "the ability to take charge of one's learning” (p. 3). In order for the learners to achieve this, they must activate a series of autonomy-enhancing strategies. Some of the strategies may include: (a) finding a suitable learning methodology, (b) setting learning goals, (c) deciding learning content and pace, (d) supervising the learning process, and (e) assessing learning achievements objectively (Zhuang, 2010). These strategies allow learners to manage their own learning by becoming more aware, more responsible, more accountable for their own decisions on what to learn, how to learn it, and when to learn it. The only way to turn learning into a more vivid and purposeful action is by empowering the learners to take control over the process.

According to Little (2004), learners' focused intention can be directed towards language learning only if three 
pedagogical principles are reinforced in the learning process. Those principles to shape autonomous learners are: (a) learner empowerment or learner involvement (b). reflectivity, and (c) appropriate target language use. Autonomous learning brings about new challenges not only to learners but also to teachers. This search for success in language learning must come from both sides. The role of the students is to gain power in order to surpass their own obstacles when learning even when the teacher is around. On the other hand, the role of teachers will always be to seek opportunities to stimulate independent, self-directed, learner-centered learning.

Following up on Holec's (1981) and Little's (1991) ideas about autonomy as taking charge of or responsibility for one's own learning, Benson (2011) accounted for a more precise definition. He defined autonomy as "the capacity to take control of one's own learning" (p. 58). His main rationale behind this decision is the idea that the construct of control is a more researchable one than charge and responsibility are. He added that autonomy must have three dimensions to be exercised: learning management, cognitive processes and learning content. Two aspects to consider in this scenario are: the complexity of the construct of autonomy, which is generally understood as comprised of many other constructs, and "the diversity of behaviors and abilities that are potentially involved in learner autonomy" (Benson, 2011 , p. 66). Both scenarios are significant to uncover the steps toward more autonomous learners in this era.

Learner engagement and motivation. Among the many elements by which maximized and successful learning is achieved, engagement and motivation have recently taken prominence. In consonance with Marks' words (2000), its logical relationship to achievement and to optimal human development makes engagement an important facet of students' learning. Engagement can also favor school retention, empower enduring outcomes and improve the social and psychological wellbeing. From this perspective, engagement yields positive effects on the development of the language learned making it a more lifelong and memorable event as students learn to connect their life goals with what they are obtaining from the learning process. On this account, possible psychological behaviors that derive from learner engagement, and can be easily detected are the following: the attention, interest, investment, and effort students expend in the work of learning. Thus, teachers may enhance engagement by appealing to both behavioral and affective participation on the students' part (Marks, 2000).

Motivation, along with engagement, is an essential element of language teaching and learning. Learner motivation may manifest itself through the levels of engagement perceived in the students within a classroom. On the words of Ryan and Deci (2000), being motivated is, "to be moved to do something. A person who feels no impetus or inspiration to act is thus characterized as unmotivated, whereas someone who is energized or activated toward an end is considered motivated" (p. 54). Thus, a highly engaged learner, who does well on language achievement, can be said to be very motivated. In this sense, a learner can be motivated towards the fulfillment of a goal intrinsically or extrinsically. Intrinsic motivation accounts for the internal drive or desire 
to achieve a goal for the joy and excitement its achievement brings. It is conducive to more lifelong personal satisfaction and success. Extrinsic motivation relates to external factors such as assessment, instructional strategies, learning conditions, educational technologies and other elements in activity systems (Gedera, Williams \& Wright, 2015). Motivation and engagement are closely related elements of language development that have a profound impact on students' language outcomes on the short or long run.

Student participation. One of the teacher's major concerns is student participation. Perhaps, from the teacher's point of view, participation is a specific behavior through which engagement and motivation manifest themselves. How to foster participation in the EFL classroom to optimize oral communication is essential. If motivation drops, the level of language acquisition success would also decrease accordingly. The use of a lesson plan based on the TBI framework requires a great deal of student participation to fulfill its goal: oral interaction and communication. The learning process depends on the level of student-student interaction and student-teacher interaction in a conducive learning environment (Biggs, 2003). In Fritschner's words (2000), participation can be understood in terms of 'talkers' who prefer 'speaking out in class', and 'non-talkers' who participate through 'attendance, active listening, sitting in their seats, doing the assignments, and being prepared for class' (p. 352). Participation thus seems to equal active learning.

An active learner keeps engaged in all the language activities through continuous involvement and participation.
In agreement with Weaver and Qi (2005), "students who actively participate in the learning process learn more than those who do not" (p. 570). That is why, it is very recommendable to implement a lesson plan following a communicative framework to maximize participation in all students. There are some important measurement criteria that can be applied to the measurement of in-class participation. Conforming to Dancer and Kamvounias (2005), five important criteria are essential to the analysis of active participation in EFL classrooms, namely preparation, contribution, group skills, communication skills and attendance. Teachers, as facilitators of the learning conditions, should be aware of the array of activities by which participation can be promoted, and which can be assessed to provide a meaningful environment for all the learners.

Assessment. Assessment has proven to be a very valuable practice to keep track of the learners' progress. In Tulu's words (2014), teachers' practice in assessment is essential as they are the ones making decisions about the process of the lessons, determining the strengths and weaknesses of alternatives available to them, making selections on their experience and making judgments about learners' progress. Different ways to approach assessment include verbal questioning and observation of student behavior. Providing immediate feedback seems to foster students' enhancement. Rather than just focusing on assessing what knowledge students have gained, teachers are encouraged to focus on why they do not learn well and what they can do to help students improve. As noted, assessment is fundamental 
to the language progress of the learners. Nonetheless, teachers are accountable for selecting the activities and techniques to carry out meaningful assessment. Meaningful assessment provides the students with the tools to be aware of what they are doing correctly or not. It provides learners with significant, clear and useful information and teachers with data to take action. Consequently, providing learners with corrective feedback should be complementary of the assessment process.

In order to tailor assessment strategies and activities to students' needs, the teacher needs to be critical enough to accommodate each possibility to the classroom situation. There is a variety of possible ideas that teachers can use. As a case in point, projects, drawings, demonstrations, videos, speeches, experiments, written reports, debates, classroom interaction, student participation, interviews, small-group discussions, individual conferences, teacher-made tests, end-of-unit tests, and standardized tests are examples of these strategies and activities.
The STAR framework. The STAR Framework was designed and implemented in response to the need for a more communication-based approach in the English courses taught at Centro de Idiomas, Universidad Nacional (CI-UNA). Its implementation started in 2010. One of the founders of this language center designed the framework based on several essential elements such as the TBI methodology, authenticity, learner autonomy, learner engagement and motivation, student participation, and assessment. These elements provided the theoretical principles that enlightened the origin of the framework.

The ultimate goal of the STAR framework is oriented towards a more communicative use of the language; in this regard, the use of the language is expected to increase and the teacher's and student's role switch as learners are taken from a teacher-controlled or skillgetting stage to a less teacher dominant stage, a more student-centered or skillusing stage (See Fig. 1). At this point, autonomy is expected to heighten. teacher-controlled

student-centered

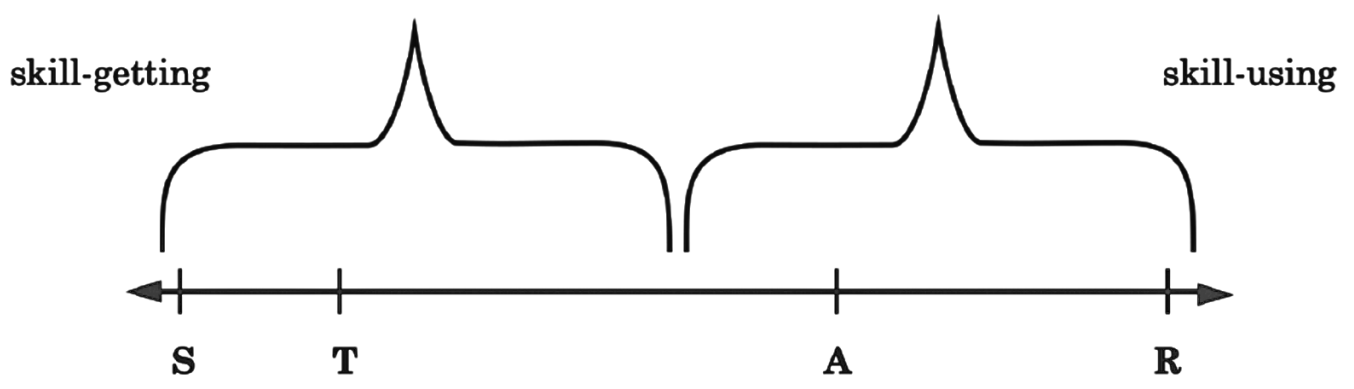

Figure 1. The roles and skill development through the use of the STAR framework in an EFL class. Researchers' own creation. 
It is worth stating that the STAR Framework is based on the implementation of the Task-based Instruction through its different stages in a language class: Starter, Tackle, Automatization, and Recycling. Each stage of this framework aligns to one of the stages of the TBI. The format facilitates the gradual development of students' use of the language. In other words, STAR was designed to maximize the autonomy of learners to communicatively interact in the target language. To achieve this, the teacher scaffolds the students' understanding of grammar rules, lexicon and expressions from the first skill-getting exercises to the final skill-using tasks.

The "S" stands for starter or any type of deinhibitizing activities, warmup, energizer, attention grabber and ice breaker included in this stage. The role of the teacher in this phase is that of a facilitator planning the type of starter and conducting it in order to either raise interest, attract students' attention to one point, topic, or lesson as a whole, to review a topic, or to enliven the class. The second stage is represented by a "T", and accounts for the stage designates as tackles. The tackles refer to those opportunities the teacher has to introduce a structure, or any linguistic item. It is carefully planned to ensure students' understanding of the topic and the use of the expected language. This is, for the most part, a teacher-centered stage. Students have little truly communicative interaction. The "A" stage represents the automaticity stage. Automaticity is one of the key principles of language teaching. In line with Brown's (2015) words, automaticity is defined as "the development of automatic skills naturally in untutored contexts with little or no analysis of the forms of language [...] without overtly noticing language forms. Learners do focus very effectively on the function (meaning) of their linguistic input and output" (p.68). That is, enough scaffolding must be given from a state of controlled language use until a state in which the learner uses language more spontaneously. The "scaffold" the teacher has provided in the first stages is cautiously removed as the students reach for the "A" stage. Indeed, once learners get to this phase, students feel more independent to select the linguistic forms they will use in the real-life task that the teacher planned for the lesson. It is remarkable to note that during this stage, the teacher swaps the role from facilitator and guide to that of a monitor. The teacher jots down ill-formed structures or mispronunciations for further analysis. The "R" stage or recycling stage allows the teacher to establish a strategy to provide corrective feedback for the students. In this phase, the teacher raises awareness of the students' mistakes collected in the previous stage.

Based on the STAR framework, the teacher can ask students to always have the reading and writing exercises done with anticipation in order to cover the four linguistic skills during the course. In other words, the teacher must not take time of the lesson to do these exercises. Most of the lesson must be devoted to listening and speaking only. Students require time to prepare their role plays, or dramatizations, for instance, and work with their classmates by sharing their knowledge. The teacher supervises the students' work and provides assistance if needed. The teacher facilitates learning, monitors it, walks around and takes notes on the mistakes the students are committing. 


\section{Research Methodology}

Researchers in this study aimed to address the extent to which the STAR format promotes more communicative EFL classes. A case study was conducted with 25 teachers and one program developer at a language school. This type of research is an empirical inquiry that inspects a phenomenon within its reallife context (Hernández, Fernández and Baptista, 2010; Yin, 1994) that could help generate knowledge and inform policy development and teaching practice (Simons, 2009). Merriam's (1988) ideas about case study in educational research aligned with the interest of this study when she explained that "The qualitative case study can be defined as an intensive, holistic description and analysis of a single entity, phenomenon or social unit. Case studies are particularistic, descriptive, and heuristic and rely heavily on inductive reasoning in handling multiple data sources" (p. 16). For this case study, the entity or phenomenon was the STAR framework as a tool to promote communicative EFL classes.

The study focused on the descriptive analysis of the following areas: ways to foster spontaneous speech, ways to promote engagement, students' confidence and risk-taking skills, learners' autonomy and classroom collaboration. To approach those areas, this study followed two main phases, with the first phase involving observations by a key informant and six teachers' logs, followed by 25 questionnaires that were answered by teachers who were chosen at random.

Procedures and participants. The primary purpose of this case study was to generate an in-depth exploration of the uniqueness of STAR in its real context while implemented in the institution where it was created. Data were collected through a three-year period. For the first phase, the events were observed in their context and teachers' perceptions were documented. To attain this, the program developer conducted a series of semi-structured observations to random classes for two years. For this stage, a teacher's log was also completed by three teachers during two class periods to collect more data. For the second phase, data were collected by means of a questionnaire that included Likert-scale ratings, a multiple-choice item and open questions.

The questionnaire surveyed teachers' experiences and perceptions of the use of STAR in their classes. The first section related to communicative principles and STAR stages. It investigated the teachers' views when assessing the appropriateness of each stage. Section two explored the types of activities teachers used the most. Section three focused on teachers' personal inventories of effective teaching activities. Drawing on teachers' comments in the form of open-ended responses, concrete ideas for strategies and activities to increase the use of the target language in class, to improve students' linguistic skills and to maximize learners' confidence and participation were subsequently identified. The data were interpreted through a combination of descriptive and thematic analysis of the open-response questions.

The participants were 25 teachers who have worked in a language school in a large public university in Southern Costa Rica for at least one year and have taught at least two different class levels. Their teaching experience ranges from novice to experienced teachers 
who have taught for more than 10 years. One of the four program developers of this language school was a key informant and researcher in this study. She has the role of academic developer whose main areas of responsibilities are to support language instructors within teaching and learning practices and to develop classroom strategies that mirror the objectives of the school.

Learning context. Costa Rica being a Spanish speaking country, language instructors teach English as a foreign language. This circumstance has direct implications on language learning that include limited practicing opportunities in their out-of-class environment, language homogeneity and the use of the native tongue in class, EFL teachers' need to always create an artificial English environment in their classrooms, short class meeting time, and the use of a decontextualized textbook is usually imposed on teachers. On this note, Mattioli (2004) identified the differences between ESL and EFL and clarified that in the former teaching environment "students most likely only speak English in the classroom, or on very limited occasions outside of the classroom. Therefore, in the EFL context, the lesson minutes are priceless slots of time for input, output, and practice" (p. 21). In their attempt to minimize the negative effects of these implications, language program developers in this setting are constantly providing teachers and students with more authentic language learning opportunities. STAR is an initiative whose attention is directed toward making taking the most out of classroom time. This lesson format was designed in 2012 and has been implemented since then.

\section{Findings}

Because of the qualitative nature of this study, the data analysis had two coding cycles as explained by Saldaña (2016). For the first cycle, open coding allowed for an initial summary of segments of data. For the second cycle, pattern coding helped identified emergent themes that eventually outlined the main final themes. This analysis included data from all data gathering instruments. Two main categories, as guided by the research questions, were generated from the analysis of all data. In terms of category one, five themes constitute the ways STAR framework promotes a communicative EFL class environment. The first category identified was meaningfulness of communicative activities; subsequently, this category generated four themes: spontaneity and risk-taking skills, engagement, learners' autonomy and classroom collaboration. For the second category, teaching strategies and classroom activities were identified. Participant-teachers generated a set of strategies and activities they valued the most to increase the use of the target language in class, improve students' linguistic skills and maximize learners' confidence and participation.

\section{Category \#1: To what extent does the STAR framework promote com- municative opportunities in the EFL classroom?}

Spontaneity and risk-taking skills. The overall data provided by both teachers and the program developer reported that by implementing this framework, teachers maximize learners' possibility to be spontaneous in class. Under this notion, language learners are said to 
produce spontaneous speech when they initiate a conversation or respond to any stimulus without resorting to any teaching material. To be considered spontaneous, students' performance must be intelligible and fluent according to the standards of their linguistic level. Even though voluntary class participation shows evidence of students' active learning, in this case we acknowledge in-class spontaneous performance as a desired goal in language learning. Drawing on behavior recorded during the observations, it was noticed that STAR provides a lot of space for students to participate spontaneously. Not only that, but teachers created a safe space where most of the students develop their confidence to provide volunteered answers and ask for clarification whenever they needed it.

Added to the voluntary participation, planned activities that boosted spontaneous speech were recorded. One instructor reported in her log that she was anxious to present to students the instructions of a class task, which consisted of presenting an impromptu speech in front of their peers. She explained that at the beginning it was challenging; however, as time passed by and students became familiar with the activity, they enjoyed sharing their thoughts. The teacher insisted that key elements to successful impromptu talks are to create a safe space, give clear instructions and provide interesting topics. Group work activities such as role-plays and simulations were always present in the classes observed and in the teachers' logs. One particular characteristic of this strategy is that students are invited to participate without much time to plan, which drove them to be creative and spontaneous to share their ideas and accomplish their group goals. In addition, there were instances where micro and macro class discussion elicited students' spontaneity to communicate a message and an opinion. The idea of promoting spontaneous performance is closely related to notions of learner confidence and risk-taking skills, as they require boldness to participate without being able to anticipate the result.

Students' type of participation portrayed them as confident and risktaking individuals. One teacher shared how spontaneous activities help develop those skills, "At the beginning, students were worried and insecure, but once they started, they became more and more comfortable. Some students even expressed at the end of the course that they had enjoyed this activity" (personal communication, October 2017). Indeed, the S stage was the one that offered more space to promote these skills. Students interrupted the class to spontaneously ask for clarification and ask for permission to make decisions. In general, some topics elicited more active participation (like in the case of crime, education and paranormal matters) while others hindered it (in the case of laws). This situation promoted teachers' reflection and analysis as shown in their logs. They asked themselves how they could include more activities with appealing topics in future classes. Correspondingly, some of the teaching behaviors that boosted confidence and risk taking were the opportunities for failing, a safe learning climate, models for risk taking, appreciation for participation and giving planned and unplanned space to participate. 
Engagement. Teaching practice has shown that many language instructors use technology, visual aids and kinesthetic activities as a hook at the beginning of their lesson to engage students. Nevertheless, once the show is over and teachers revert to more traditional teaching strategies, students fail to remain engaged. This was not the case with instructors using STAR. As documented through observations and logs, and in alignment with some theoretical contributions, engagement was detected through students' attention, interest, investment, and effort in their learning process. On this note, curiosity appeared as a common trend. Being curious has the implication of asking questions, and that was the case of students in this study. Indeed, students showed curiosity about the meaning of new words and the pronunciation of some others. They were in constant search for improving their linguistic performance to the point that there are records of students who interrupted the class to verify their language understanding and clarify doubts. However, their questions were not limited to language learning and their interest in some topics also promoted discussions.

A remarkably long attention span was also a perceived sign of learners' interest. The observations recorded 30-minute activities were students were immersed in the tasks without losing track of what was happening. In this regard, Brown (2000) explained that as learners grow older, their attention span tends to lengthen as long as intrinsically motivating topics and activities are presented to them. There were only few cases of shy students who did not participate orally as frequently and voluntarily as the rest; however, they were always on-task and assumed their roles and duties with responsibility. Related to curiosity is the idea of learners' initiative. This behavior was recorded in different scenarios where students raised questions and provided comments. First, some students initiated class discussions about the meaning and use of words. This practice gave the teacher the opportunity to expand on topics that otherwise would be omitted. Second, a relaxed and encouraging class environment allowed some learners to take the lead when making decisions about group work and roles. Student-initiated negotiations were recorded when deciding moderators' roles, taking the lead to answer exercises and provide feedback, deciding on articles to read and proposing characters for role-plays.

For this study, students' investment and effort to learn a language are closely related and linked to the notion of affective factors. Consequently, it was recorded that in spite of the difficulties some students had to produce well-constructed sentences, they had the courage to participate in class. Also, active participation was found when checking exercises on the board. During those times, students were attentively taking notes to identify and correct their own mistakes. Voluntary participation was a constant norm that showed effort to learn. In fact, as noted in the observations, learners volunteered eagerly for most of the time. Another behavior that showed learners' investment was the frequent consultation with the teacher outside class time. In this regard, students even brought magazines to ask their instructor questions, which revealed that they did not limit their learning 
to what took place in the classroom; on the contrary, they took charge of their own learning and were constantly taking opportunities to improve their language skills. This self-learning motivation is closely linked to the notion of learner autonomy.

Learner autonomy. Autonomy can be understood as a mental state or a behavior. While the latter is easily observable, the former needs to be inferable from either observable behavior or learning outcomes (Benson, 2011). Understanding autonomy from Benson's (2011) lens led to the idea that autonomy is the capacity to control learning. Even though this capacity cannot be observed, it is the exercise of this capacity that was recorded. Four core aspects of autonomy were identified: empowerment or involvement, ability to plan learning, language learning self-monitoring and language-learning improvement. Regarding students' involvement and empowerment, stage $A$ in the frame documented a higher level of autonomous participation from students. Indeed, they were constantly taking the initiative to follow up on topics and questions they were interested in. Learners' empowerment in language use in spite of their basic level was clear in the way they took control over social interaction with their instructor and peers. They were constantly asking clarifying questions, responding to classmates' doubts and starting class discussions about decisions to be made. Students' involvement was also documented through their commitment to class participation. During all activities, learners were actively involved not only in participating in the activities but also in paying attention and honoring their classmates' efforts and performance.

In relation to language learning selfmonitoring, instructors guided learners in this process through keeping a portfolio and asking them to self-assess their language skills and ability to perform the task at hand. In different stages of the framework, students used a rubric designed by the teacher so that they could reflect on grammar, pronunciation, vocabulary, relevant ideas and preparation. The constant use of this strategy made students aware of their ability to control of their behavior in their learning process. The last aspect, related to how STAR fosters autonomy, is related to the notion of language-learning improvement. Though measuring the linguistic gains of students is a complex matter, in this study we could document students' progress as observations were conducted in a three-year span. Stage A was the time of the lesson that best made this aspect evident. As students ventured to participate, they interacted a lot by using English and doing so voluntarily. It was observed that students' interaction moved from phrases and short sentences to more accurate and longer performance. In the last stages of the observations, learners structured more complete and accurate statements in oral form. Much of their performance was associated with the wide collaborative opportunities they had.

Classroom collaboration. Three major components of the communicative approach were recorded throughout the study: socially oriented activities, problem-solving tasks and small group interaction. They are all tied with the notion of classroom collaboration. Regarding socially oriented activities, 
because of the structure of the lesson, teachers were able to provide many activities that allowed students to socialize. This socialization factor included topics of social interest like education systems, paranormal and supernatural powers, crime, social networks, and life goals. On a similar note, problemsolving tasks constituted an important part of the classes recorded. Students had many opportunities to work in groups and collaborate with each other to pursue a common goal. Examples of these tasks were (a) simulating a radio show where they were responsible for providing convincing facts about the importance of good sleep; (b) creating an emergency plan for a hurricane alert for their community; (c) creating a survival plan; (d) designing a new law to eradicate any social problem they consider urgent in their country and (e) participating in group competitions. These competitions took the form of language games were students were grouped to win a prize. When students were surprised, intrigued and focused on a goal, that evidence that they are vividly experiencing meaningful contact with the language.

Small group interaction was a constant practice in different stages of the lessons. However, it was the way they were intertwined with feedback and role-taking strategies that draws attention. Peer feedback was fully embedded in the classes recorded. In detail, during different stages of the class, but most frequently in the A stage, students were invited to give peer feedback by completing anonymous forms that were transferred to the board in the form of notes for students to analyze together. Through a collaborative discussion, learners identified errors and provided a better way to communicate ideas. This collaboration helped students understand what was considered good language communication and why. The instructors maintained a moderator role in those discussions. Another example is the exhibition type of presentations (photo gallery, award ceremony, art museum) that assigned students the role of critics. They walked through stands and used a form provided by the teacher to give specific feedback about preparation and communication skills. Students were required to give strong arguments to back up their comments and recommendations, which demanded from them a critical point of view and assertive communication skills to transmit their ideas effectively.

An extension to the understanding of group work is the need to develop interactional skills effectively. It was found throughout this study that instructors consciously assigned roles to students. For instance, in one class observation, the instructors assigned the roles of scribble, drawer and presenter when working on a poster design. Students were familiar with the roles and performed them as expected. In addition, one instructor recorded in her log how students themselves had decided on dividing their work and assigned a duty to each member of the group. By effectively adopting and developing a role, students assured understanding on the part of the listener and the speaker, and were able to channel their anxiety, doubts and excitement. Added to this, a very important element for meaningful language learning is that when disagreements and interruptions occurred, learners were challenged to rephrase and start the conversation again to get their message across. 
Category \#2: What strategies and activities can boost students' linguistic skills with a communicative focus within the STAR framework?

\section{Communicative teaching strategies} and learning activities. Language instructors who participated in this study provided a valuable inventory of activities and strategies that they use under the STAR Framework. Participants' ideas support the argument that learning is more effective when students are involved in rich-communicative environments were relevant tasks are the core of the lesson rather than in traditional teacher-led classes. Their ideas were organized by stage in the framework. For the first stage, the leading teaching strategies were group work, games and creative prompts. Teachers documented the use of videos in this section through a clear description of how they used them was not given. Teachers agreed that these strategies and activities are necessary to motivate and engage learners since they prepare them for the class. On this note, games in the language classroom play a key role as they provide spontaneous spaces to interact with others. Indeed, LarsenFreeman and Anderson (2011) agreed that games are meaningful because of their common features with real communicative interaction.

Regarding the $\mathrm{T}$ stage, most of the instructors found grammar, vocabulary and pronunciation explanations appropriate to introduce the topic of the lesson. Though this stage has more teacher-led characteristics, participants supported the idea that the STAR Framework is flexible as it gives room to real communication activities even at this moment of the class development. Some teaching strategies suggested by teachers include providing learning activities that incorporate authentic material, providing learning demonstration options, providing multiple instructional visuals and providing teacher-student interaction. They insisted on the role of technology in visual aids. The main argument in favor of this material is that it increases learners' levels of on-task behavior, concentration, and involvement in the target activity. This matches Harmer's (2007) findings that these types of input help students improve their language production, acquire the language in an easier manner, and increase their confidence since they prepare them to use the language in real life situations.

For Stage A, participants agreed that not much control from the teacher is required at this stage since it gives students the opportunity to take a more active, participative role. However, they noted that students require some guidance, as they are not fully independent. This notion did not undervalue the idea that students' involvement was always observed in this stage. They all reported documented to have used debates, skits, talk shows, and roundtables during this stage, which proved that group work is a core teaching strategy used. Finally, the R stage was considered an essential strategy to assess students and give them as much positive feedback as possible. Though teachers reported to have used teacher, peer and self-assessment strategies, teacher assessment showed to be the one used the most. The most common way to achieve this was through direct clarification of errors. They did this mainly in the form of shared group error analysis as they considered it to 
be less threatening for learners, and it maximized students' involvement in the analysis of their own and their peers' errors. The way instructors promoted participation in this stage was a key finding. On this note, they used a variety of games to encourage feedback such as board games, bingos, group and individual competitions. Video analysis was another feedback activity described in which students had the chance to go over their language errors. They also used formative quizzes and journal writing as alternative assessment strategies for students with intrapersonal skills.

\section{Conclusions}

After examining the related literature, the STAR Framework and its effect on promoting communicative classes, we can conclude that the approach under study it exposes learners to an array of benefits. STAR allows teachers to maximize learners' spontaneity in class. Such space fosters students' confidence to provide voluntary answers and ask for clarification. This framework also creates risk taking opportunities through activities such as impromptu talks, role-plays, and simulations. However, these activities are developed in a safe environment where participation is appreciated and failing is part of the learning process. Students' engagement is also identified within STAR. The results of the study reported learners' interest and curiosity towards the activities developed in class, a long attention span is long, and time and effort investment in learning by initiating discussions and negotiations of meaning.
These behaviors also lead to learners' autonomy, which is evidenced through empowerment or involvement, the ability to plan learning, language learning self-monitoring, and language learning improvement. In addition, STAR boosts classroom collaboration by involving students in socially oriented activities, problem-solving tasks, and small group interaction. Socialization is a key element in the communicative approach, and by means of STAR, teachers are able to incorporate topics of social interest, encourage students to work collaboratively to accomplish a common goal, and have learners provide and receive feedback.

There is a vast repertoire of activities that participating teachers have acknowledged as effective and language-generating along the process of using the STAR framework. Teachers acknowledge those activities as communicative as long as they are used and presented following the stages of the framework. The $\mathrm{S}$ stage is filled with attention catchers that motivate students and keep them engaged in the learning process. The $\mathrm{T}$ stage encourages students to participate actively, be spontaneous, and take risks. This stage supports comprehension of grammar, vocabulary, and pronunciation, provides necessary input for students to improve their language production, increases learners' confidence, and prepares them with all the skills required to produce later on. The A stage guarantees language production. Here learners are active and take up a more autonomous role, and they interact and collaborate with each other to complete tasks and improve their language skills, especially speaking. Interaction and negotiation of meaning in this stage 
allows students to use the language creatively. Finally, the $\mathrm{R}$ stage maximizes and enhances comprehension of linguistic forms in the way of teacher, peer or self-assessment. Collaborative feedback in this stage enhances the meaningfulness of language learning.

One of the conclusions drawn from the analysis of the STAR framework takes the form of a recommendation for teaching and learning. It was observed that this lesson plan model and the language school in which it is used have shown a clear interest in promoting authentic language learning. Principles of the learner-centered approach have shown to be of benefit for students. Learners in this program showed to be ready to have a more active role in decisions about content, assessment and critical reflection. There is plenty of room for language strategy training of metacognition as well. These practices can eventually help students adopt a more active role from which they will take ownership of their work and their ideas. This shift will open space for collaboration and dialogue between the learners and instructors. All in all, the STAR framework proved to be effective in the sense that it demonstrated to integrate more communicative activities which foster spontaneous speech, heighten engagement, increase confidence and risktaking skills, boost learners' autonomy and build up collaboration in the EFL classroom.

\section{Bibliography}

Benson, P. (2011). Teaching and researching autonomy. Harlow, UK: Pearson.
Biggs, J. (2003). Changing university teaching for quality learning at University London. England: The Society for Research into Higher Education and Open University Press.

Brandl, K. (2008). Principles of communicative language teaching and task-based instruction. Qommunicative Language Teaching in Action: Putting Principles to Work. New Jersey: Pearson Prentice Hall.

Carter, R., \& Nunan, D. (2001). The Cambridge guide to teaching English to speakers of other languages. Cambridge: Cambridge University Press.

Council of Chief State School Officers (CSSO). (2012). Distinguishing formative assessment from other educational assessment labels. Washington: Council of Chief State School Officers.

Dancer, D., \& Kamvounias, P. (2005). Student involvement in assessment: A project designed to assess class participation fairly and reliably. Assessment \& Evaluation in Higher Education, 30(4), 445-454.

Ellis, R. (2010). The methodology of task-based teaching. In P. Robertson \& R. Nunn (Eds.), The Asian EFL Journal Cebu Conference Proceedings August 2009. Australia: Asian EFL Journal A Division of Time Taylor International Ltd. Retrieved from http://www.asian-efljournal.com/PDF/The_Asian_EFL_ JournalCEBU_conf.pdf

Fritschner, LM. (2000). Inside the undergraduate college classroom: Faculty and students differ on the meaning of student participation. The Journal of Higher Education, 71(3), 342-62.

Gedera, D., Williams, J., \& Wright, N. (2015). Motivation, Leadership 
and Curriculum Design. In C. Koh (ed.) Identifying factors influencing students' motivation and engagement in online courses (pp.1322). Singapore: Springer Science and Business Media.

Gilmore, A. (2007). Authentic materials and authenticity in foreign language learning. Language Teaching, 40(2), 97-118.

Harmer, J. (2007). The practice of English language teaching. London, UK: Longman.

Hernández, R., Fernández, C. \& Baptista, P. (2006). Metodología de la investigación. Mexico, D.F.: McGraw-Hill Interamericana.

Hedge, T. (2000). Teaching and Learning in the Language Classroom. Oxford: Oxford University Press.

Holec, H. (1981). Autonomy in foreign language learning. Oxford: Pergamon.

Howatt, A.P.R. (1984). A History of English Language Teaching. Oxford: Oxford University Press.

Johnson, K. \& Morrow, K. (1981). Communication in the classroom: Applications and methods for a communicative approach. London: Longman.

Kilickaya, F. (2004). Authentic materials and cultural content in EFL classrooms. The Internet TESL Journal, 10(7). Retrieved on January 20th from http//www.metu.edu.tr.kilickay/

Larsen-Freeman, D., \& Anderson, M. (2011). Techniques and principles in language teaching. Oxford: Oxford University Press.

Little, D. (1991). Learner autonomy: Definitions, issues and problems. Dublin: Authentik.

Little, D. (2004). Democracy, discourse and learner autonomy in the foreign language classroom. Utbildning \& Demokrati, 13(3), 105-126.
Littlewood, W. (1981). Communicative language teaching: An introduction. Cambridge: Cambridge University Press.

Lee W. (1995). Authenticity revisited: Text authenticity and learner authenticity. ELT Journal 49 (4), 323-328.

Long, M. (1985). A role for instruction in second language acquisition. In K. Hyltenstam and M. Pienemann (eds.). Modelling and Assessing Second Language Acquisition. Clevedon, Avon: Multilingual Matters.

Marks, H. (2000). Student engagement in instructional activity: Patterns in the elementary, middle and high school years. American Educational Research Journal, 37, 31.

Mattioli, G. (2004). On native language intrusions and making do with words: Linguistically homogeneous classes and native language use. English Teaching Forum, 42(4), 20-25.

Merriam, S.B. (1988). Case study research in education: A qualitative approach. San Francisco, CA: Jossey-Bass.

Newton, J. (2001). Options for vocabulary learning through communication tasks. ELT Journal, 55,30-37.

Nunan, D. (2004). Task-Based language teaching. Cambridge: Cambridge University Press.

Prabhu, N. S. (1987). Second language pedagogy. Oxford: Oxford University Press.

Richards, J.C. (2001). Curriculum development in language teaching. Cambridge: Cambridge University Press.

Richards, J. (2006). Communicative language teaching today. New York: Cambridge University Press. 
Ryan, R. M., \& Deci, E. L. (2000). Intrinsic and extrinsic motivations: Classic definitions and new directions. Contemporary Educational Psychology, 25, 54-67.

Sánchez, A. (2004). The task-based approach in language teaching. University of Murcia, Spain: International Journal of English Studies. Retrieved from https://files.eric. ed.gov/fulltext/EJ1072205.pdf

Saldaña, J. (2016). The coding manual for qualitative researchers. London: SAGE.

Simons, H. (2009). Case study research in practice. London: SAGE.

Thornbury, S. (1999). How to teach grammar. England: Pearson Educated Limited.

Tomlinson, B. (2003). Humanizing the course-book. In B. Tomlinson (Ed.),
Developing materials for language teaching. London: Continuum Press. Tulu, G. (2014). ELF classroom assessment: Teachers' practice and teachers' techniques adjustment in Ethiopia. Educational Research and Reviews. Vol. (9) 20. pp 10291071. 23 de Octubre, 2014.

Weaver, RR, \& Qi, J. (2005). Classroom organisation and participation: College students' perceptions. Journal of Higher Education, 76(5), 570-601.

Zhuang, J. (2010). The Changing Role of Teachers in the Development of Learner Autonomy- Based on a Survey of "English Dorm Activity". Journal of Language Teaching and Research. 